\title{
Recurrent Inverted Schneiderian Papilloma
}

National Cancer Institute

\section{Source}

National Cancer Institute. Recurrent Inverted Schneiderian Papilloma. NCI Thesaurus.

Code C115432.

The reemergence of inverted Schneiderian papilloma after a period of remission. 